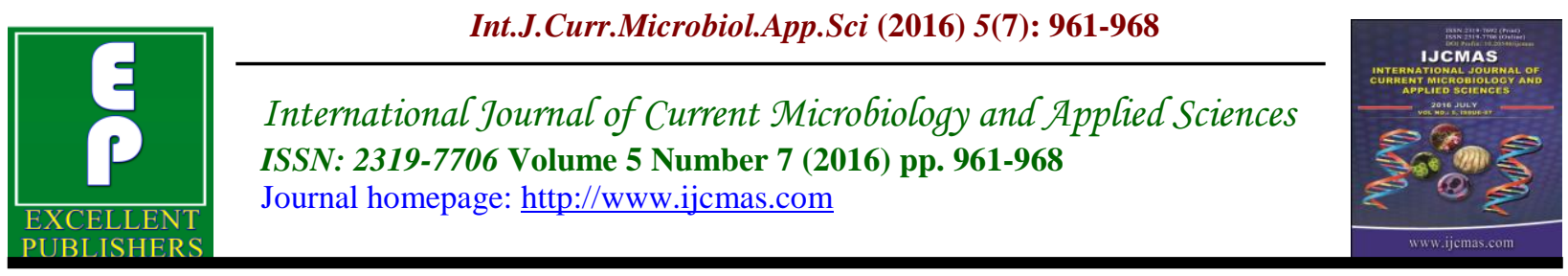

Original Research Article

http://dx.doi.org/10.20546/ijcmas.2016.507.108

\title{
Molecular Detection of Salmonella Isolated from Poultry Farms in Abia State Southeast Nigeria
}

\author{
Nwiyi Paul*, F. Chah Kennedy and S.V.O. Shoyinka \\ Department of Veterinary Microbiology and Parasitology, College of Veterinary Medicine, \\ Michael Okpara University of Agriculture, Umudike, Department of Veterinary Pathology and \\ Microbiology, Faculty of Veterinary Medicine, University of Nigeria \\ *Corresponding author email id:
}

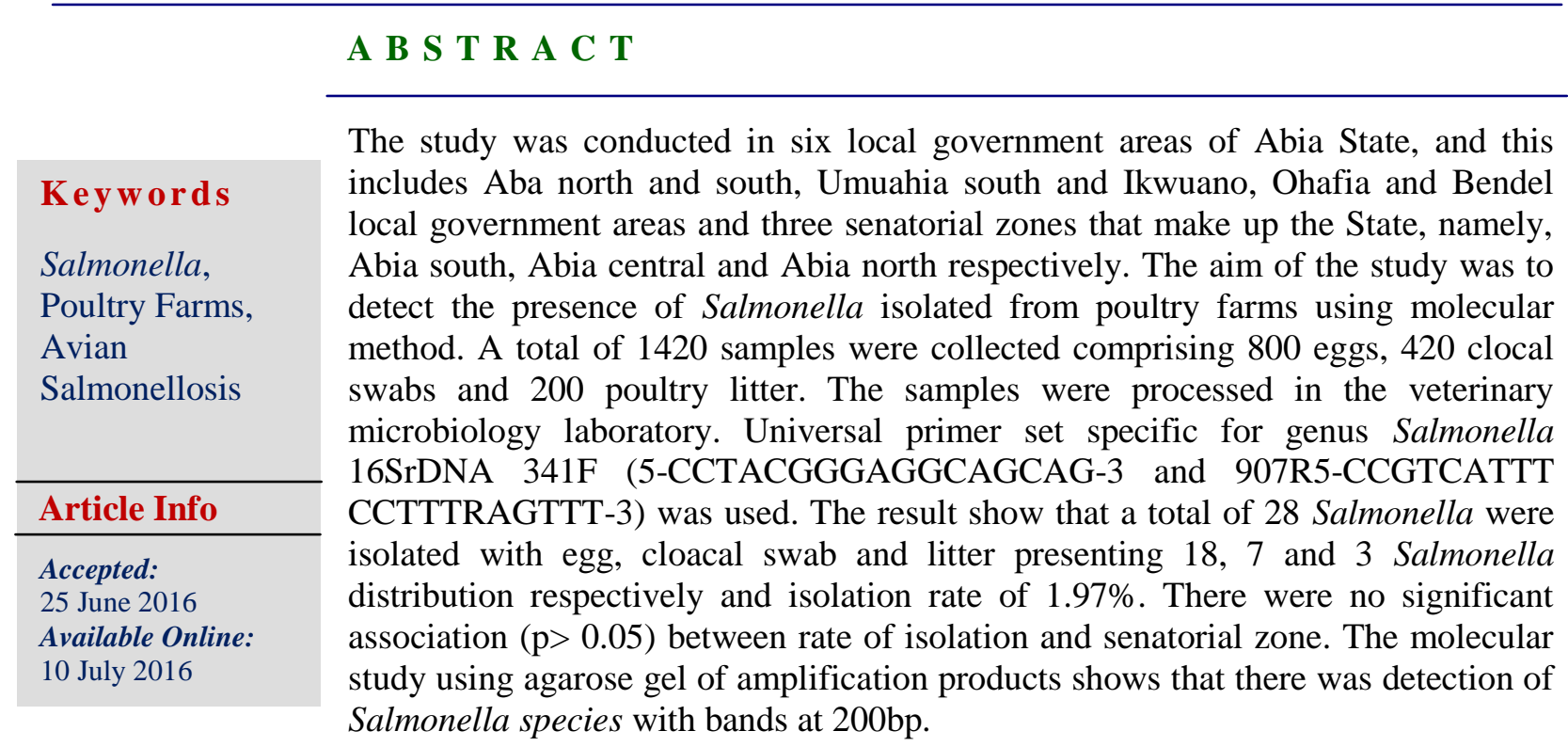

\section{Introduction}

Salmonellae are Gram-negative, short pump rods, non-spore forming, non-capsulated, aerobic and facultative anaerobic organisms and classified under the family enterobactericeae (OIE Manual, 2006). Avian salmonellosiss is the disease of birds caused by members of the genus Salmonella with particular reference to Salmonella pullorium and Salmonella gallinarum (Jordan, 1990). Disease caused by Salmonella infections is most common in Chicks under 2 weeks of age and is rarely seen in birds of 4 weeks of age for pullorum disease while fowl typhoid occurs among adult birds (Khan et al., 1998). The morbidity and mortality vary considerably and deaths are usually less than $20 \%$ of the affected group but in exceptional cases can approach 100\% (Lulful-Kabir, 2010).

The clinical signs as described by FreitasNeto et al., (2007) are depression, weakness, anorexia and dropping wings. Others are drop in egg production, prostration and apathy (Ezema et al., 2009). Confirmation 
of the diagnosis is by isolation and identification of the causal agent. In chick dying in the septicemia phase, salmonellae can be isolated directly from the liver, gall bladder or yolk sac, but the intestines and particularly the caecal contents are the most rewarding site to culture (OIE, Manual, 2004).

There are different sources Salmonella can invade farms, Salmonella infection can be from faecal contamination of eggs, introduction of Salmonella into a country via importation of live poultry or hatchable eggs and ineffective vaccination using live Salmonella vaccine (Bensink and Botham, 1983). Rats and mice are documented source of Salmonella and are attracted to the Poultry house by abundance of easily accessible food (Pomery and Nagaraja, 1991). Domestic flies and bettles are both capable of transmitting salmonellae and infection can persist through the insects from one generation to another via eggs and larva (Bustian and Aize, 2007). There has been several molecular methods of characterization of Salmonella with each method having merits and demerit (Sabat et al., 2003). These include; Polymerase Chain Reaction (PCR), Pulsed-Field Gel Electrophoresis (PFGE) and Random Amplification of Polymorphic DNA (RAPD). Polymerase chain reaction (PCR) is based on using the ability of DNA polymerase to synthesize new strand of DNA complementary to the other template strand. Since DNA polymerase can add a nucleotide only onto a pre-existing $3^{\prime} \mathrm{OH}$ group, it needs a primer to which it can add the first nucleotide. This requirement makes it possible to delineate a specific region of template sequence that the researcher wants to amplify (NCBI, 2014).

The Pulse-Field Gel Electrophoresis is a standard molecular typing method used to analyze centre to centre transmission and have been successfully used in large scale microbiological and epidemiological investigations (Mac Dougal et al., 2004). The use of Random Amplification of polymorphic DNA (RAPD) is based on the parallel primers that target several unspecified genomic sequences. RAPD has been widely used for the typing of bacterial isolates in cases of disease outbreaks (Lenin et al., 2011). Poultry provides income for small and medium scale farmers in Nigeria, but suffers from major limitations of disease like Salmonella which results in low egg production, low performing breeds and poor feed conversion. This study is necessitated due to the increasing complain of poultry farmers of incidences of Salmonella in the study area.

\section{Materials and Methods}

\section{Study Area}

This study was conducted in Abia State Southeast of Nigeria. Abia State lies between latitude $4^{\mathrm{O}} 40^{1}$ and $6^{\circ} 14^{1}$ north and longitude $7^{\circ} 10^{1}$ and $8^{\circ} 10^{1}$ east. The state is bounded by Rivers State in the south, Ebonyi State in the north, Imo State in the west and Akwa Ibom State in the east. The population of Abia State is 4.3 million, while farming and trading are the major occupation (FRN, 2007).

\section{Study Population}

Chickens in poultry farms and hatcheries in Abia State contributed the study population.

\section{Sampling Technique and Sample Collection}

A multistage sampling method was employed in this study. In the first stage, Abia State was purposively selected out of 
the 5 states in the region based on complaint by many farmers of failures of fowl typhoid vaccine administered to their birds. The sample collection cut across the three senatorial zones that make up the state. In the second stage, two Local Government Areas (Aba south and north, Ikwuano and Umuahia south, Ohafia and Bendel Local Government Areas of Abia State) were randomly selected from each of the three senatorial zones in the state.

Egg, cloacal swabs and litter samples were used for the study. Eggs were collected and placed in polythene and then kept in a plastic box and transported to the veterinary laboratory for processing. Cloacal samples were collected by placing sterile swab stick into the vents of the chicken, gently rotated before withdrawal while the litter was collected by using sterile spatula to collect $10 \mathrm{~g}$ of litter on the floor of the poultry house into a sterile universal bottle and then transported to the laboratory for processing. The sample collection lasted for a period of 10 months, from July 2014 to April 2015.

\section{Isolation of Salmonella from Egg, Cloacal and Litter}

Isolation of Salmonella was done according to the procedure described by Zancan et al. (2000). A loopful of pooled egg were inoculated into peptone water (enrichment broth) and incubated at $37^{\circ} \mathrm{C}$ for 24 hour. Each cloacal swab sample was inoculated into peptone water (Pre-enrichment broth) and incubated at $37 \mathrm{oC}$ for 24 hours. Similarly, for poultry litter approximately $5 \mathrm{~g}$ of poultry house manure were placed into a universal bottle containing $10 \mathrm{ml}$ of physiological buffer saline. The poultry manure samples were inoculated into peptone water and incubated at $37 \mathrm{oC}$ for 24 hours. All other procedures apply for eggs, cloacal and litter samples. A loopful of the pre-enrichment broth was inoculated into
Rappaport-Vassiliads (RV) broth (enrichment broth) and incubated at $42^{\mathrm{O}} \mathrm{C}$ for 24 hours. After incubation, the RV broth was streaked on Macconkey agar and deoxysocholate citrate agar. Inoculated plated were incubated overnight at $37^{\mathrm{O}} \mathrm{C}$ and observed for colourless (non lactose fermenting) colonies suspicious of Salmonella. The Salmonella suspected colonies were subcultured to MacConkey media for purification.

\section{Biochemical Tests}

Biochemical tests were conducted using Simmon citrate agar, Urease agar, Triple sugar Iron, Sugar fermentation test Motility test, Methyl red and Vogues Proskauer test to confirm if the isolates were Salmonella phenotypic ally.

\section{Genomic DNA Extraction Protocol}

Genomic DNA was extracted using the boiling method according to the protocol of Danifor Biotechnology (2012) stock culture of the organism was sub-cultured on MCA and incubated at $37^{\circ} \mathrm{C}$ for 24 hours. After incubation, three colonies of each isolate were collected and added to $200 \mu \mathrm{l}$ buffer AL (containing lysostaphin) and mixed thoroughly by vortexing.

The suspension was incubated at $56^{\circ} \mathrm{C}$ for 10 mins, after which $200 \mu 1$ absolute ethanol was added, mixed thoroughly by vortexing and then one milliliter of the mixture was pipette into the DNase mini spin column. The spin column was placed in a $2 \mathrm{ml}$ collecting tube and centrifuged at $\geq 6000 \mathrm{Xg}$ for $1 \mathrm{~min}$. The flow-through and the collecting tube were discarded. The spin column was placed into a new $2 \mathrm{ml}$ collecting tube and $0.5 \mathrm{ml}$ buffer AWI, was added and centrifuged for $1 \mathrm{~min}$ at $\geq 6000 \mathrm{Xg}$. The flow through and the collecting tube were discarded again. The 
spin column was placed in a new tube and $0.4 \mathrm{ml}$ of buffer AW2 was added and centrifuged at $20,000 \mathrm{Xg}$ for 3 mins. The flow-through and the collecting tube were again discarded. The spin column was transferred into a new 1.5 or $2 \mathrm{ml}$ microcentrifuge tube. The DNA was eluted by adding $0.2 \mathrm{ml}$ of buffer $\mathrm{AE}$ to the center of the spin column and finally centrifuge for 1 min at $\geq 6000 \mathrm{Xg}$ in other to increase the yield.

\section{Amplification of Target DNA}

The target DNA was amplified by the Polymerase chain reaction (PCR). The procedure described by Promega Cooperation, Madision USA was conducted in a volume of $25 \mu \mathrm{L}$ containing $20 \mu \mathrm{L}$ of genomic DNA from each Salmonella Isolate. A volume of $30 \mu \mathrm{L}$ of the supernatant was used as template for amplification by PCR assay. The sequence of a pair of primer specific for the genus Salmonella (16SrDNA341F5-CCT-ACGGGA-GGC-AGC-AG-3 and 907R5-CCGTCA-ATT-CCT-TTR-AGT-TT-3), Inqaba Biotechnical Industries South Africa was used.

A known Salmonella strain was used as positive control. Reactions with the primer were carried out in a total volume of $25 \mu \mathrm{L}$ amplification mixture consisting of $2.5 \mu \mathrm{L}$ of
$10 \mathrm{X}$ reaction buffer $(500 \mathrm{mM} \mathrm{KCL}, 200 \mathrm{mM}$ Tris- $\mathrm{HCl})$ of each primer $(10 \mathrm{mM}), 0.6 \mu \mathrm{L}$ of Taq DNA polymerase (fermentase). $3 \mu \mathrm{L}$ of extracted DNA as template and $9.6 \mathrm{~L}$ of distilled water. Amplification was performed in Techne TC512 thermocycle. The cycling conditions were as follows: 35 cycles of denaturation at $94^{\circ} \mathrm{C}$ for $30 \mathrm{~s}$, annealing at $56^{\circ} \mathrm{C}$ for $90 \mathrm{~s}$, elongation at $72^{\circ} \mathrm{C}$ for $30 \mathrm{~s}$, and final extension period for $10 \mathrm{~min}$ at $72^{\circ} \mathrm{C}$. Amplified products were electrophorased in $1.5 \%$ agarose gel and a $100-b$ DNA ladder was issued as a size maker. After staining with ethidium bromide, the gel were visualized and photo graphed under transilluminator ultra-violet (UV) light with gel documentation apparatus (MB Fermentase USA).

\section{Results and Discussion}

A total of 1420 samples obtained from 43 farms in Abia State were processed for Salmonella isolation. Out of the 1420 samples processed, $40(2.81 \%)$ produce nonlactose fermenting colonies on MacConkey while only $24(60.0 \%)$ were urease negative. The inability of the isolate to hydrolyze urea and the negative indole-reaction obtained is in agreement with Muktaruzzaman et al. (2010). The utilization of Simmon Citrate by the isolates was consistent with the finding of Lee et al. (2003).

Table.1 Number of Farms and Local Government Areas Selected For the Study

\begin{tabular}{ccc} 
State & Local government area & No. Of farms selected \\
\hline Abia & Aba north & 14 \\
& Aba south & 11 \\
& Umuahia south & 6 \\
& Ikwuano & 5 \\
& Ohafia & 3 \\
& Bendel & 4 \\
\hline Total & $\mathbf{6}$ & $\mathbf{4 3}$ \\
\hline
\end{tabular}


Table.2 Salmonella distribution location and number sampled from eggs, fecal swab and poultry litter in Abia State.

\begin{tabular}{cccccc}
\hline Location & No. sampled & Egg & Cloacal swab & Litter poultry & Isolation rate (\%) \\
\hline Ohafia & 60 & - & - & - & 0.00 \\
Bendel & 60 & - & 1 & - & 1.66 \\
Umuahia South & 180 & 2 & 1 & - & 1.66 \\
Ikwuano & 120 & 1 & 0 & - & 0.83 \\
Aba south & 610 & 9 & 3 & 2 & 2.30 \\
Aba north & 390 & 6 & 2 & 1 & 2.30 \\
\hline Total & $\mathbf{1 4 2 0}$ & $\mathbf{1 8}$ & $\mathbf{7}$ & $\mathbf{3}$ & $\mathbf{1 . 9 7}$ \\
\hline
\end{tabular}

Table.3 Isolation Rate of Salmonella in Poultry Farms in Abia State.

\begin{tabular}{cccc}
\hline $\begin{array}{c}\text { Senatorial } \\
\text { zone }\end{array}$ & $\begin{array}{c}\text { No of samples } \\
\text { processed }\end{array}$ & $\begin{array}{c}\text { No positive for salmonella } \\
\text { isolates }\end{array}$ & $\begin{array}{c}\text { Isolation rate } \\
(\%)\end{array}$ \\
\hline Abia North & 200 & 2 & 1.00 \\
Abia Central & 420 & 6 & 1.43 \\
Abia South & 800 & 20 & 2.50 \\
\hline Total & $\mathbf{1 4 2 0}$ & $\mathbf{2 8}$ & $\mathbf{1 . 9 7}$ \\
\hline
\end{tabular}

Fig.1 Map of Abia State showing the three senatorial zones

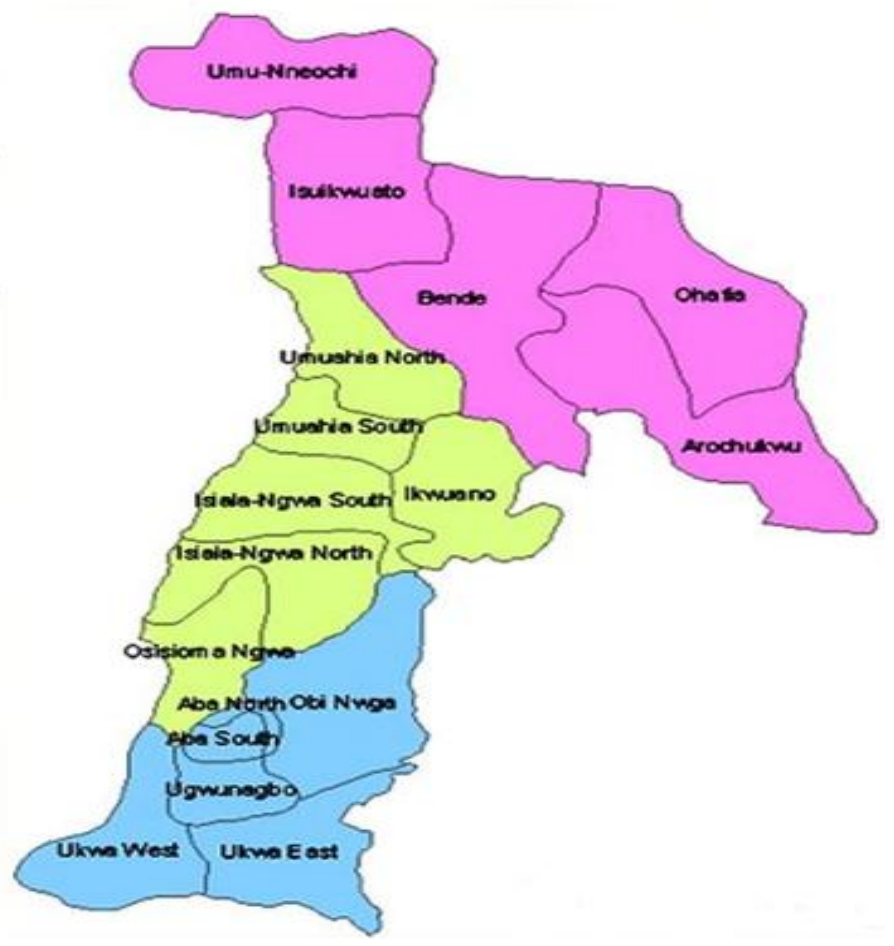




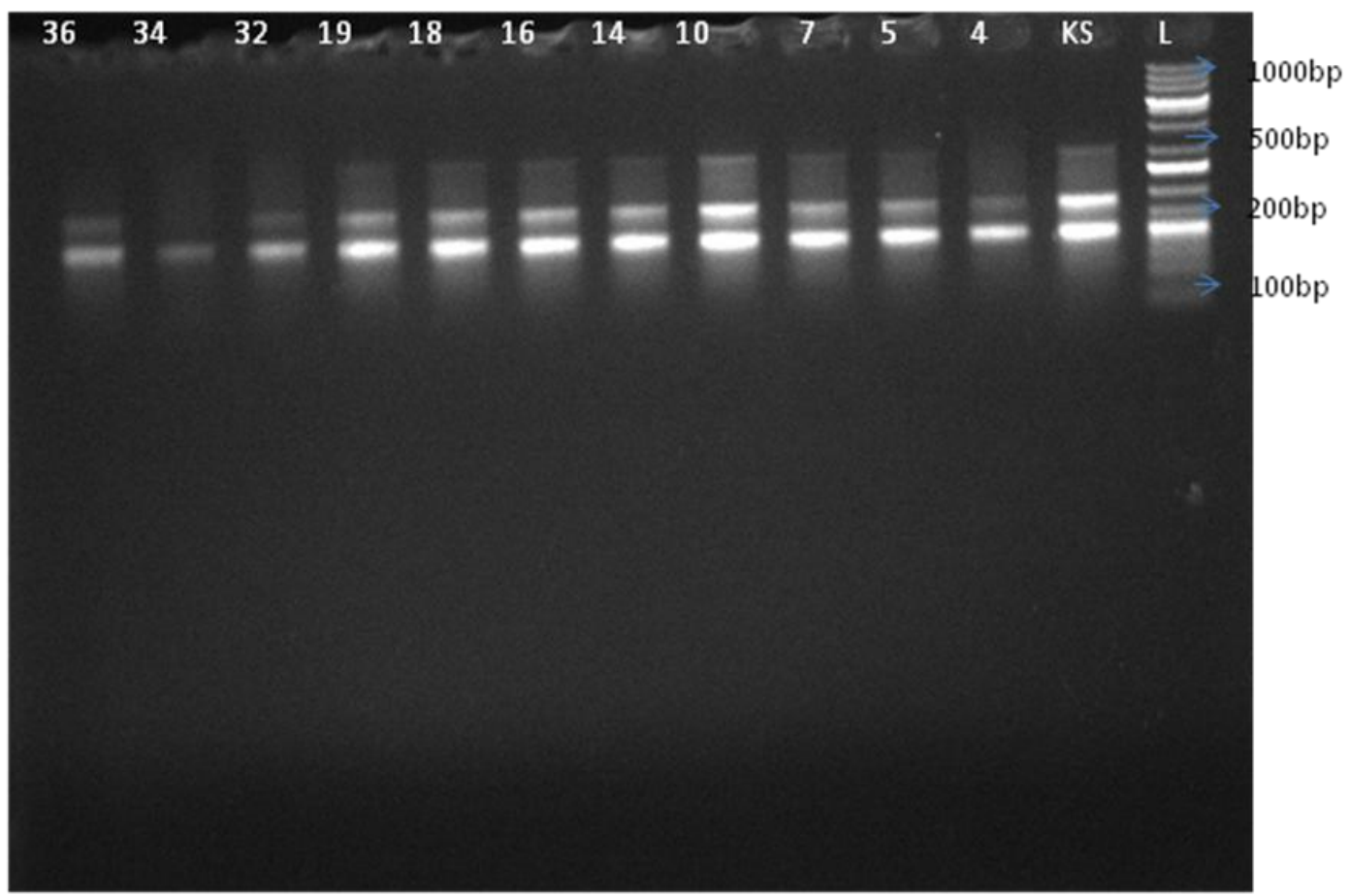

Plate 1: Representative agarose gel of amplified products using universal Salmonella primer set. L is 100bp-1kbDNA ladder (molecular marker). Lanes $36,32,18,19,16,14,10,7,5,4$, are positive for Salmonella species with bands at 200 while lane 34 is also positive for Salmonella species with band at 200bp.KS is known Salmonella strain

The 24 isolates agglutinated in Salmonella poly $\mathrm{O}$ antiserum but did not agglutinate poly $\mathrm{H}$. The distribution of Salmonella in the six local government areas ranges from $0.0 \%$ to $203 \%$.

The study shows that Aba north and south has the highest with isolation rate of $2.30 \%$ each while Ohafia local government area has the least with $0.0 \%$ suggesting that farms in Ohafia local government area are Salmonella free. This may be due to high management levels practiced by the poultry farmers in that area and right use of vaccine. The isolation rate ranges from $1.00-2.50 \%$ in the three senatorial zones of Abia State with Abia south having the highest predominant isolation rate of $2.50 \%$. There was no significant association $(\mathrm{P}>0.05)$ between isolation rate and senatorial zone.

From the study, the Salmonella isolation rate in Abia State was $1.97 \%$ and this is closely related to the findings of Suresh et al. (2006) who reported a $1.86 \%$ isolation rate in new Delhi, India but in disagreement with AlAbadi et al. (2011), who reported Salmonella isolation rate of $9.2 \%$ in Dharka, region of Bangladesh. The reason for this low isolation rate may be due to several factors like use of vaccination, good hygiene practices, restriction of poultry farm attendant from moving from one poultry farm to the other and the source of day old chicks. 
Universal primer set were used to detect/confirm the Salmonella species by Polymerase chain reaction. Salmonella species processed by PCR produced bands with amplicon size of 200bp following gel electrophoresis and ethidium bromide staining of the PCR product (Plate 1).

This is in line with the work carried out by Dione et al. (2011), but in disagreement with the findings of Zahravi et al. (2005). Zahravi et al. (2005) in his work carried out in Shiraz City in South of Iran using different primers reported amplification of Salmonella DNA with amplification size of $284 \mathrm{bp}$. The difference in amplification size could be due to differences in primer type use. This finding is closely related to that of Kwon et al. (2010) who reported the amplification of Salmonella with amplicon size of 197bp. The primer type used in this study is the same with that used by Kwon et al. (2010).

\section{References}

Al-Abadi, I.K.M., Al-Mayah, A.A.S. 2011. Isolation and identification of Salmonella Spp from Chicken and Chicken environment in Basrah Province. African J. Biol. Sci., 7: 3334.

Bastian, A., Aize, G. 2007. Animal Microbiology: Escherichia coli. Blackwell Scientific Publication Oxford, London, Edinburg, Melbourne Pp: 94-102.

Bensink, J.C., Botharn, F.P 1983. Antibiotic Resistant Coliform bacilli, isolated from freshly slaughtered poultry at retail outlets. Australian Vet. J., 60: 80-83.

Danifor $\quad$ Biotechnology. 2012. www.omicsonline.org/biotechnology 2012/

Dione, M.M., Ikumapayi, U., Saha, D.,
Mohammad, N.L., Adegbola, R.A., Greerts, S., Leven, M., Antonio, M. 2010. Antimicrobial resistance and virulence genes of non-typhoidial Salmonella isolates in the Gambia Senegal. J. Infect. Devel. Countries, 5: 765-775.

Ezeman, W.S., Onuoha, E., Chah, K.F. 2009. Observations on an outbreak of fowl typhoid in commercial laying birds in Udi, Southeastern Nigeria. Comparative Clin. Pathol., 18: 395 398.

Freitas Neto, O.C., Penha, R., Filho, C. 2010. Sources of human non-typhoid salmonellosis: A review Revista Brasilerira decienciaa aviocola, 12: 1-11.

FRN. 2007. www.viewphotos. org/ nigeria/flat-map-of-Aba-443.html.

Jordan, F.T.W. 1990. Poultry disease $3^{\text {rd }}$ edition.

Khan, A.H., Bari, M.R., Das, P.M., Ali, M.Y. 1998. Pullorum Disease in semi-mature chicken and its experienced pathology. Bangladesh Vet. J., 32: 124-128.

Kwon, Y.K., Kim, A., Kang, M.S., Her, M., Jung, B.Y., Lee, K.M., Jong, W. Kwon, J.H. 2010. Prevalence and Characterization of Salmonella Gallinarum in the Chicken in Korea during 2006 to 2008. Poultry Sci., 89: 236-242.

Lee, Y.J., Kim, K.S., Kwon, Y.K., Tak, R.B. 2003. Biochemical characteristics and antimicrobial susceptibility of salmonella gallinarium isolated in Korea. J. Vet. Sci.

Lutful-Kabir, S.M. 2010. Avian Collibacillosis and Salmonellosis: A closer look at epidemiology, pathogenesis, diagnosis, control and public health concerns. Int. J. Environ. Res. Public Health, 7: 89114. 
MacDougall, L., Fyfe M., Mclintyre, L., Paccagnella, A., Cordner, K., Kerr, A. 2004. Frozen Chicken nuggets and Strips: A Newly Identified risk factor for salmonella Heidelberg infection in British Columbia, Canada. J. Food Protection, 67: 1111-1115.

Mukatruzzaman, M., Haider, M.G., Ahmed A.K.M., Alum, K.J., Rahman, M.M. 2010. Validation and Refinement of Salmonella pullorum (SP) coloured antigen for diagnosis of Salmonella infections in the field. Int. J. Poultry Sci., 9: 801-808.

National Center for Biotechnology information, 2014. Primer based approach for PCR amplification of high GC content gene: mycobacterium gene as a model. Molecular Biology International, http//dx.doi.org/10.1155.2014/937308

OIE. Manual. 2004. OIE Manual Part 2: Pullorum Diseases and Fowl Typhoid. In OIE Manual Diagnostic Tests and Vaccines for Terrestrial Animals. $4^{\text {th }}$ Edition Paris, France.

OIE, Manual. 2006. Fowl typhoid and pullorum disease. In: Terrestrial Manual. Office international des Epizooties (OIE), Paris, France. Pp 538-548.
Pomeroy, B.S. and Nagariaja, K.V. 1991. Fowl Typhoid in: Disease of Poulty, $9^{\text {th }}$ edition . B. W. M. Calnek, H. J. Barnes, C. W. Beard, W. M. Read and H. W. Yoder Jr. eds. Iowa State University Press, Ames, Iowa. Pp 8799.

Saba, G., Rose, P., Hickey, W.J. 2003. Selective and Sensitive method for PCR amplification of Escherichia coli 16SRNA genes in soil. Appl. Environ. Microbiol., 66: 844-849.

Wong, T.I., Nicol, C., Cook, R., MacDiarmid, S. 2007. Salmonella in uncooked Retail meats in New Zealand. J. Food Protection, 7: 13601365.

Zaharvi, S.T., Mahzounleh, M., Saeedzadel, A. 2005. The isolation of antibioticresistant Salmonella from intestine and liver of poultry in Shiraz province. where Salmonella serovar typhimurum co-exists in strains with a plasmid of the 23 in-compatibility groups. Microbiol. Pathol., 15: $237-$ 242.

Zancan, F.T., Berchieri, J.A., Fernandes, A. S., Gama, N.M. 2000. Salmonella investigation in transport boxes of day old birds. Brazilian J. Microbiol., 31: 230-232.

\section{How to cite this article:}

Nwiyi Paul, F. Chah Kennedy and S.V.O. Shoyinka. 2016. Molecular Detection of Salmonella Isolated from Poultry Farms in Abia State Southeast Nigeria. Int.J.Curr.Microbiol.App.Sci. 5(7): 961-968. doi: http://dx.doi.org/10.20546/ijcmas.2016.507.108 